\title{
38. SUMMARY OF LITHOSTRATIGRAPHIC FINDINGS AND PROBLEMS
}

\author{
W. D. Nesteroff, University of Paris, France \\ F. C. Wezel, University of Catania, Italy \\ and \\ G. Pautot, Centre Océanologique de Bretagne, France
}

\section{INTRODUCTION}

A vast range of sedimentary types were drilled on Leg 13 (Figures 1 and 2). This results from the fact that the Mediterranean Sea is surrounded by continents, divided into basins, and receives terrigenous inputs from various geographic areas. None of the sedimentary types was found alone at any site. Even the thick accumulation of turbidites and grain flow deposits of the Nile Cone display some pelagic layers interbedded with the turbidites. This demonstrates the diversity of the sedimentary history of the Mediterranean Sea and the many changes that occurred during its geological history.

In this chapter we wish to present a summary of our lithological discoveries, classified according to genetic group, and briefly to introduce the lithological problems raised. The genetic groups involved are: (a) pelagic deposits, (b) turbidites and contourites, (c) slump and tectonically affected deposits, (d) volcanic deposits, (e) evaporitic series, (f) sapropels, (g) continental deposits, (h) basement, and (i) special problems. The reader interested in the stratigraphic succession of the sedimentary types at each site will find it presented in detail in the lithostratigraphy part of each site chapter.

\section{PELAGIC DEPOSITS}

Pelagic sediments were encountered in more than half the sites of Leg 13, in the Atlantic and the Mediterranean Sea (see Sites 120, 121, 125, 126, 127, 129, 130, 131, 133, and 134).

The single hole on Gorringe Bank, in the Atlantic (Site 121), was drilled into exclusively pelagic sediments before reaching basement. In the Mediterranean Sea, pelagic nanno oozes or marls were encountered in the majority of the holes. However, because of their different lithologies, the Miocene and the Plio-Quaternary deposits will be discussed separately. Miocene pelagics were recovered at three sites: in the Alboran Sea (Site 121, in the Ionian Basin (Site 126) and at the foot of the Strabo Mountain (Site 129). Pliocene and Quaternary pelagics were cored throughout the Mediterranean, but recovery was not always successful. Two complete sedimentary columns were recovered (at Site 132 in the Tyrrhenian Sea and at Site 125 in the Ionian Basin) while in the Alboran Sea, at Site 121, a postCalabrian pelagic section was found above turbidite beds. Elsewhere, short or fragmentary sections were recovered from the Balearic Basin (Sites 133 and 134) and the Strabo Mountains (Site 129). Finally, thin, but very significant, pelagic intercalations were observed on the Nile Cone (Sites 130 and 131) where pelagic oozes are interbedded with the turbidites, and in the Hellenic Trench where a bed of
Pliocene pelagic ooze underlies the Quaternary turbidite fill.

\section{Atlantic Ocean: Gorringe Bank}

Pliocene and Quaternary sediments comprise lightcolored, white or orange gray foraminiferal oozes (Figure $3)$. The calcium carbonate content is high. The exact stratigraphic location is not known but must be near the surface ( 0 to $60 \mathrm{~m})$.

Lower Miocene deposits cored between 60 to 69 meters are nanno oozes, also with a high calcium carbonate content. They are light gray, massive, homogeneous, and stiff.

An important hiatus probably separates the Miocene from the underlying lower Cretaceous shaly marls. The latter are low in calcium carbonate, dark-colored, and laminated. They are mainly composed of fine terrigenous clastics and there is some evidence of diagenesis. Cretaceous marls occur between 137 and 251.7 meters, where they overlie basement.

The lowest Cretaceous sediments comprise a hemipelagic ooze, the fine terrigenous constituent being higher than the biological products. The laminations dark color, low proportion of calcium carbonate, and absence of bioturbation are indicative of euxinic conditions on the bottom.

The important hiatus (60 to 80 my?) that separates Cretaceous and Miocene sediments has been noted in some other marginal Atlantic sites (Hollister, C. D., Ewing, J. L. et al., 1972; Hayes, D. E., Pimm, A. C. et al., in press). It may be interpreted as a phase of nondeposition or even erosion by bottom currents during this time span.

Pelagic sedimentation resumed during the Miocene with high carbonate nanno oozes, suggesting that open-sea conditions prevailed over Gorringe Bank with depths similar to those of today.

\section{The Mediterranean Sea}

\section{The Miocene Mediterranean Pelagics}

Miocene pelagic deposits are different from the overlying Pliocene and Quaternary pelagic sediments. On the one hand they contain a high proportion of fine terrigenous debris and, on the other, they show some indications of euxinic conditions.

\section{Alboran Basin Miocene Pelagics (Site 121)}

Tortonian hemipelagic marls, with occasional graded sands or sandstones, overlie the basement between 686 and 864 meters (Figure 4). The marls are dark colored, poor in calcium carbonate $(30 \%)$, finely laminated, and become brittle and fissile with increasing lithification. The bulk of the sediment comprises fine terrigenous clastics. The rate of sedimentation is $2.8 \mathrm{~cm} / 10^{3} \mathrm{y}$. 


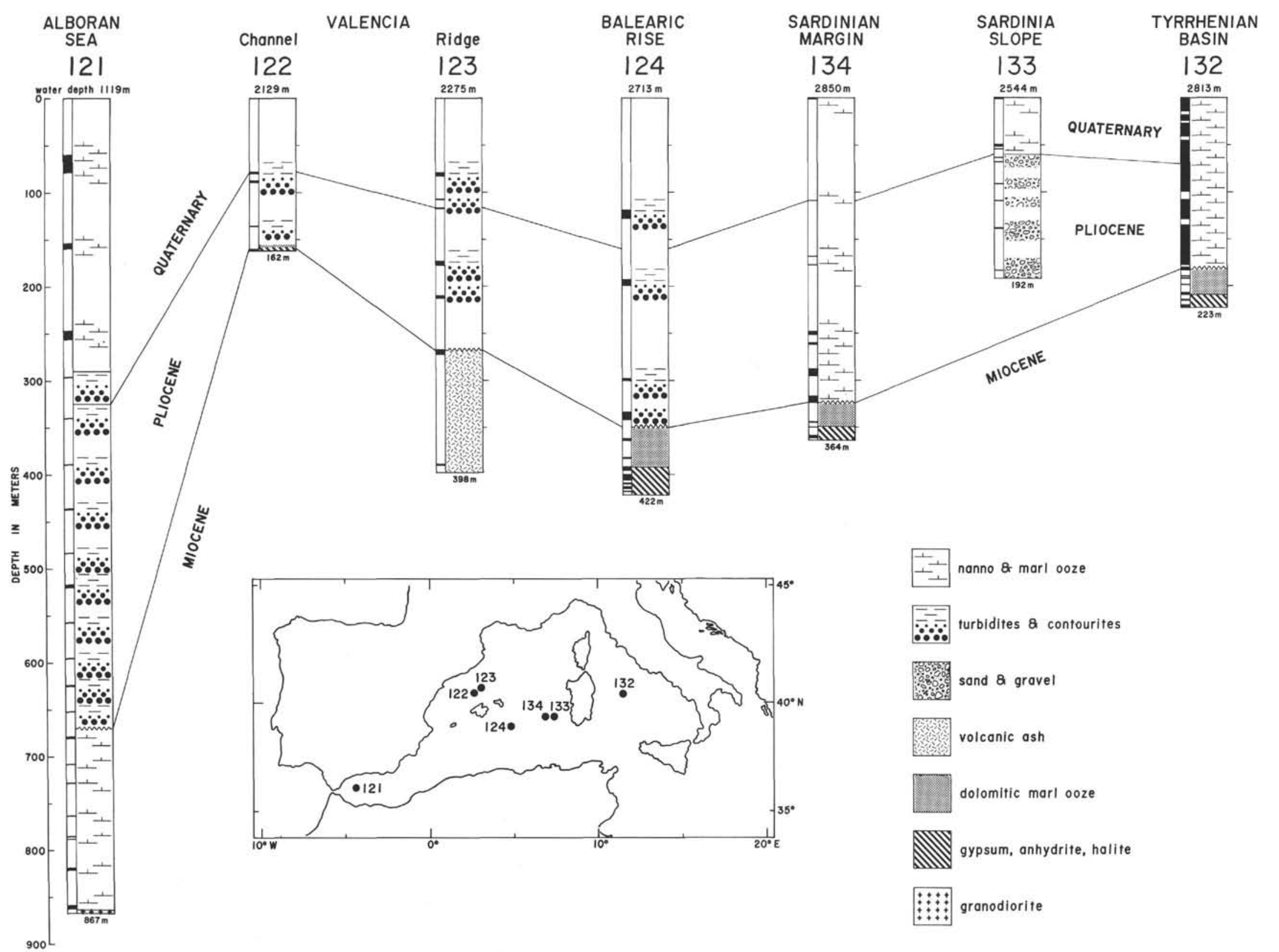

Figure 1. Leg 13 sites in the western Mediterranean Basin. Schematic lithostratigraphic columns. 



Figure 2. Leg 13 sites in the eastern Mediterranean Basin. Schemattc lithostratigraphic columns. 


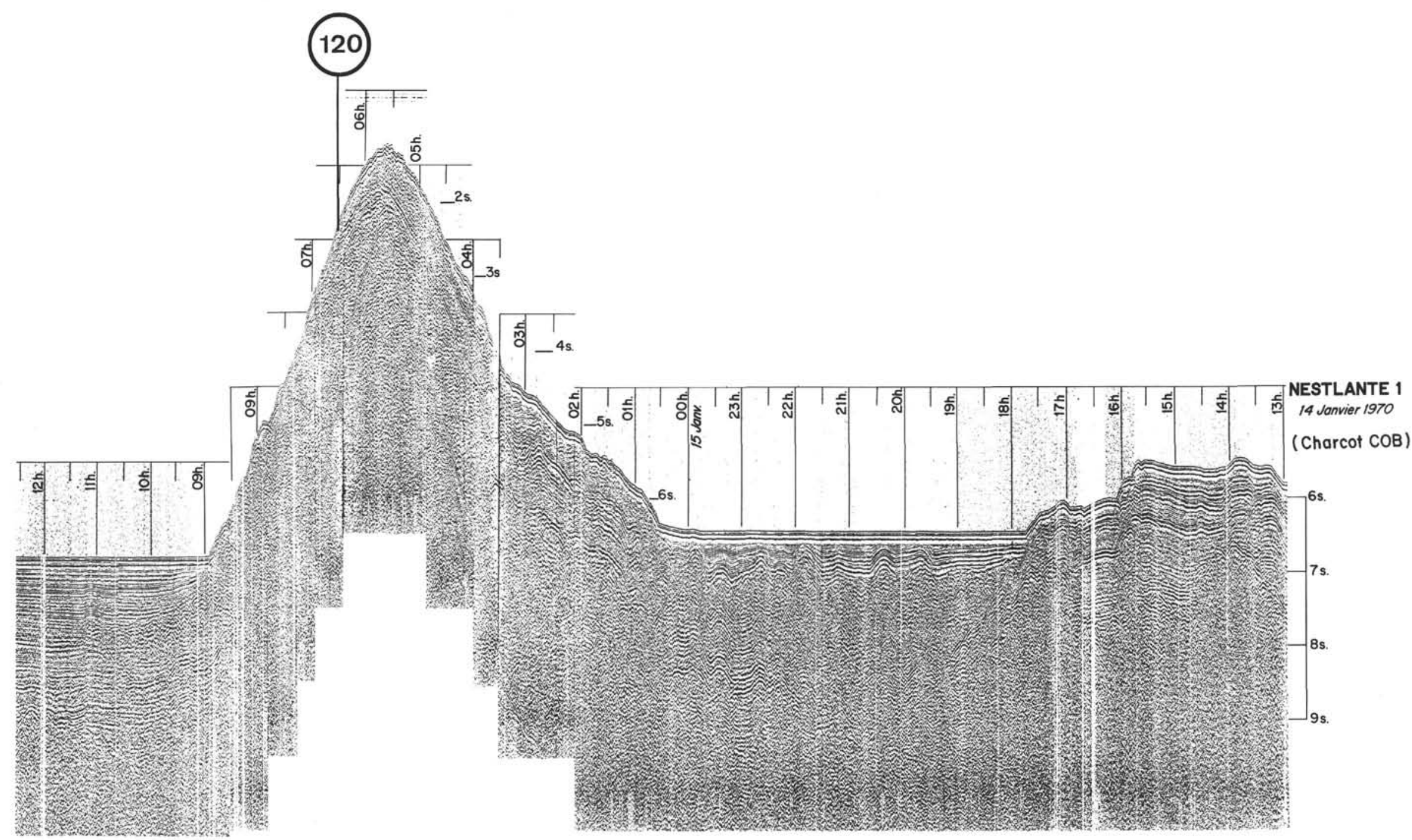

Figure 3. Gorringe Bank; reflection profile (N-S) and position of Site $120(R / V$ Charcot cruise Nestlande I). The drilling recovered Pliocene and Miocene pelagics on top of Cretaceous pelagics before reaching a gabbro basement. 


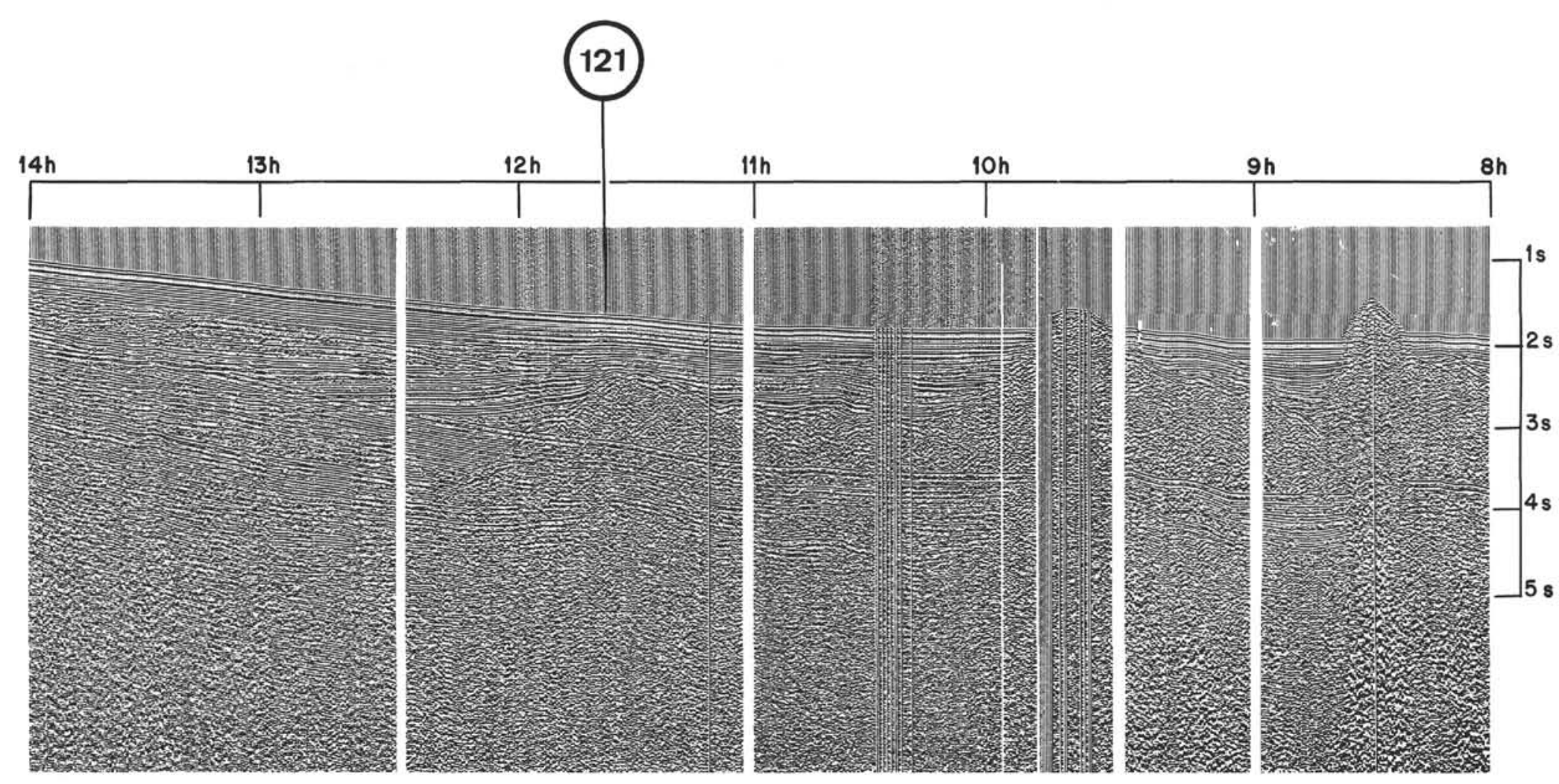

Figure 4. Western Alboran Basin; reflection profile (NW-SE) showing the position of Site $121(R / V$ Charcot cruise Polymede I). The drilling penetrated Quaternary hemipelagic oozes on top of Pliocene turbidites. A marked unconformity separates the Pliocene from underlying Tortonian hemipelagic marls. The basement is metamorphic. 
These deposits suggest a small basin where fine terrigenous influxes overwhelm biogenic products. The dark color, fine lamination, pyrite, and lack of bioturbation indicate the scarcity of bottom life. The interbedded graded sands point to occasional and rare turbidity currents.

The Ionian Basin Miocene Pelagics (Site 126)

Middle Miocene hemipelagic marls were drilled at Site 126, taking advantage of a deep cleft in the Mediterranean Ridge. The recovered sediments are very dark gray marls of Serravalian age which are very poor in calcium carbonate $(5-13 \%)$. They are laminated and become brittle and fissile at depth.

Dwarfed foraminifera, both planktonic and benthonic, together with abundant nannoplankton are notable. This fauna, the dark color, the low calcium carbonate content, the laminations, the pyrite, and the lack of bioturbation suggest euxinic bottom conditions.

The Strabo Mountain Miocene Pelagics (Site 129)

Middle and upper Miocene hemipelagic deposits were drilled at the foot of the Strabo Mountain in the Hellenic Arc (Site 129). The exact stratigraphic succession is not known, as we may be dealing with slumped sediments or tectonic mélange. In addition, all the sediments are partly or completely dolomitized, presumably in a later stage.

The older sediment drilled at Site 129 is a piece of foraminiferal limestone of Langhian age, indicating opensea conditions.

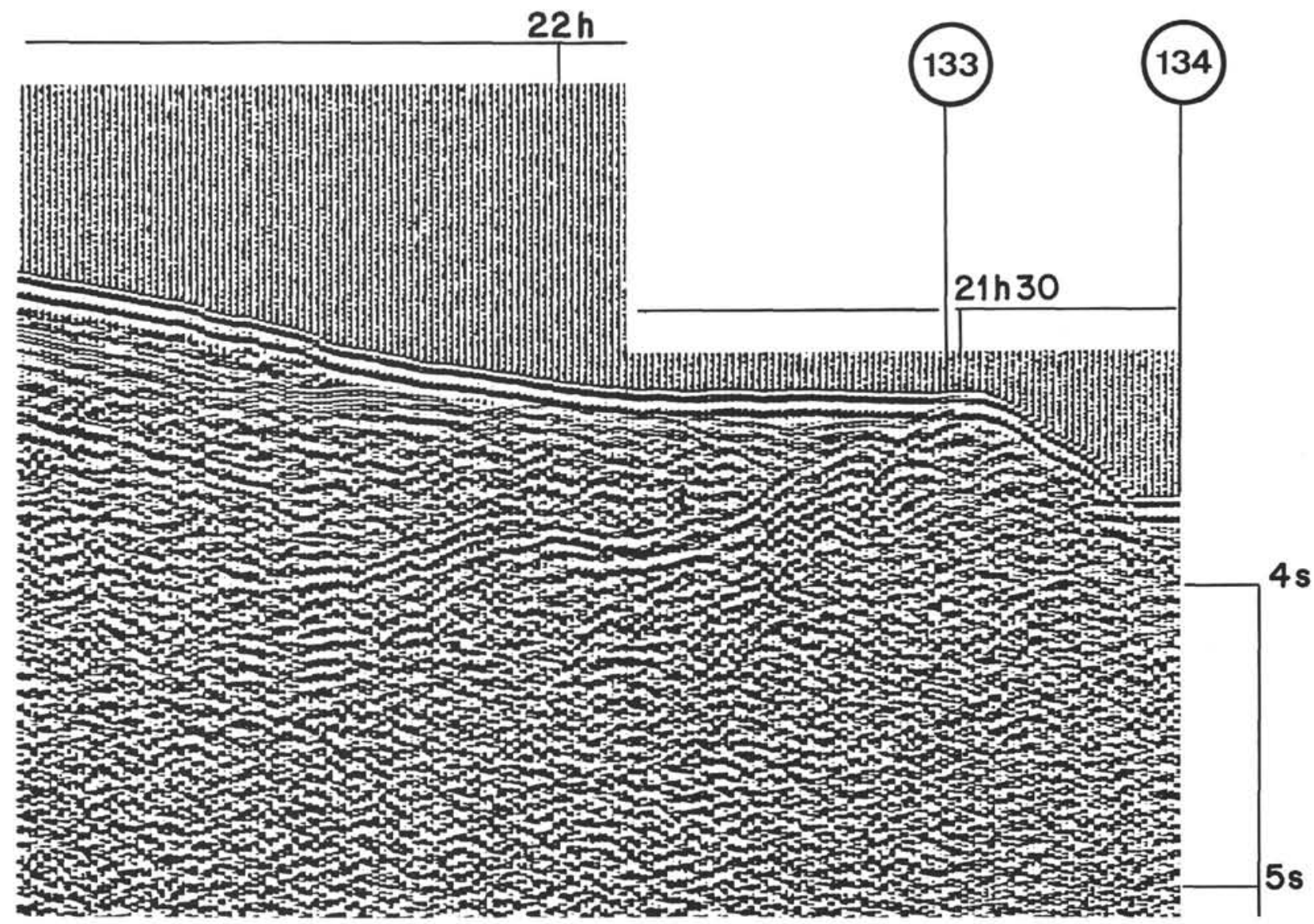

Figure 5. Pelagic nanno ooze, light colored and rich in calcium carbonate, interbedded with Nile turbidites. The latter consist mainly of black clay, poor in calcium carbonate. Note the bioturbation of the top of the lower turbidite sequence $(130-1-2,25$ to $30 \mathrm{~cm}$, on scale. Figure 6.

Serravalian and Tortonian dolomitic oozes and dolomitic marl oozes were recovered above the Langhian. They comprise large proportions of terrigenous silts and clays together with a foraminiferal and nannoplankton fauna. Oblique laminations underlined by concentrations of silt or foraminifera, suggest bottom current activity.

At this site, Langhian open-sea conditions, were replaced during the Serravalian and Tortonian by more terrigenous facies.

\section{Pliocene and Quaternary Pelagics}

The Alboran Basin Pelagics (Site 121)

At Site 121 , which is probably not characteristic of the whole of the Alboran Sea, the upper lithologic unit (60 to $290 \mathrm{~m}$ ) comprises marl oozes of Quaternary age (Figure 4). They are greenish gray, plastic, and show few visible structures. The dominant constituents are fine terrigenous debris, the biogenic carbonate fraction being low $(25-35 \%)$. The rate of sediment accumulation is high: $19.9 \mathrm{~cm} / 10^{3} \mathrm{y}$.

This is a typical hemipelagic deposit for a small basin receiving a high fine terrigenous influx. This unit probably extends to the present floor (see Huang and Stanley, 1972).

The Balearic Basin Pelagics (Sites 133 and 134)

In the Balearic Basin, pelagic marl oozes were penetrated only at Sites 133 and 134 on the Sardinian margin (Figure 5).

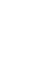


At Site 133, a very short section of foraminiferal marl ooze of Quaternary age was recovered. The sediment is highly calcareous and contains foraminifera and nannoplankton in equal proportions. Pebbles and sands interbedded with this pelagic ooze suggest that turbidity currents may have been active at that time.

At Site 134, situated farther from land and overlapping the deep buried margin (Figure 18), two holes penetrated the Pliocene deposits. In Hole 134, there comprise pelagic marl ooze which lies uncomformably above Miocene evaporites.

In the pelagic ooze, a high calcium carbonate content reflects a high proportion of nannoplankton and foraminifera $(50-62 \%)$. Of note are: current reworking, folding and compressional patterns, and, up to 30 meters above the unconformity, an admixture of well-rounded gravels.

In Hole 134E, a side wall core penetrated the PlioceneQuaternary boundary represented by a mineralized crust.

Quaternary deposits were penetrated in all the holes of Site 134 , but with poor recovery. They comprise marl oozes similar to the Pliocene material. Current reworked horizons are more frequent than in the Pliocene and large gravels and pebbles are of note. The rocks are semi-schists similar to the Palaeozoic of Sardinia. Closer to land, in Hole $134 \mathrm{~A}$, the marls oozes are distinctly more terrigenous, grading to clays, and suggesting a massive input of fine terrigenous clastics.

The seven sedimentary columns penetrated in Sites 133 and 134 show transgressive Pliocene and Quaternary pelagic deposits encroaching gradually on the Sardinian margin.

\section{The Tyrrhenian Sea Pelagics (Site 132)}

Hole 132, located in the Tyrrhenian Sea, was cored continually. It penetrated 182 meters of oozes representing sedimentation from the beginning of the Pliocene to the present before entering Miocene evaporites.

The pelagic sediments are formaniferal marl oozes to marl oozes. There is a general trend from the base to the top. At the base, the oozes have a high calcium carbonate content; a high proportion of foraminifera, which are apparent on a freshly split core; no stratification; lighter colors, with gradational changes; abundant hydrotroilite spots; and burrowings. On the other hand, the Recent oozes near the sea floor surface are poorer in calcium carbonate and foraminifera. They are bedded with sharp color changes and contain layers of ash, together with beds of foraminiferal and terrigenous sand.

The whole sedimentary column is a light-colored tan or olive gray, indicating an oxidizing environment. The lower half, Pliocene in age, displays homogeneous, high-carbonate deposits which are similar to the early Pliocene (Zanclian of Seguenza) creamy white foraminiferal marls of Sicily and Calabria called Trubi (cf. Baldacci, 1886). In Sicily, the unit is up to 100 meters thick and is transgressive over the underlying gypsum beds (see Decima \& Wezel), this volume, Chapter 44.1). It is composed of 10 to 15 percent foraminifera, of which more than 90 per cent are planktonic. The Trubi rate of sedimentation in Sicily is between 2 and $3.5 \mathrm{~cm} / 10^{3} \mathrm{y}$. At Site 132 , the rate of accumulation of the lower Pliocene ooze is $3 \mathrm{~cm} / 10^{3} \mathrm{y}$.
The upper part of the sedimentary column is more terrigenous and shows sharp changes in sedimentation probably resulting from climatic fluctuations. The interbedded sand layers point to some reworking by bottom currents.

The pelagic oozes of Site 132 lie unconformably on the evaporitic series. At their base the pelagics are brecciated and hematite stained, suggesting penecomtemporaneous deformation and terrigenous influxes.

Ionian Sea Pelagics (Site 125)

On the Mediterranean Ridge (Site 125), pelagic deposits were continuously cored before the drill string penetrated Messinian evaporites (at $79.75 \mathrm{~m}$ ). The sedimentary column represents pelagic sedimentation in the Ionian Basin during the Pliocene and the Quaternary.

The sediments grade from foraminiferal nanno oozes near the bottom to plastic marl oozes at the top. Gradual changes are of note such as an increase in fine terrigenous influx (from 25 to 50\%) together with a decrease of foraminifera from bottom to top. Also, the deposits all show sharp contacts along bedding planes. A great variety of colors occurs in different beds, but the colors are always light.

As at Site 132, the Pliocene deposits are slightly different from the Quaternary deposits. A basal high carbonate facies is overlain by more terrigenous deposits. The bottom conditions are oxygenated except during short periods of restricted circulation when sapropel beds were deposited. The bedding, well developed in all the columns, suggests that in the eastern basin the oceanic circulation was at all times more restricted and consequently the pelagic sedimentation more dependent on productivity variations than in the western basin. This is possibly reflected in the rates of sediment accumulation which vary from 2.3 to $3.8 \mathrm{~cm} / 10^{3} \mathrm{y}$.

\section{The Eastern Basin Pelagics (Site 129)}

At Site 129, situated at the foot of the Strabo Mountain, pieces of consolidated and unconsolidated sediments of Pliocene and Quaternary age were recovered. The interpretation is difficult because of a possible tectonic mélange in this area of the Hellenic Arc.

Drilling showed that the slope of the Strabo Mountain is covered by a hard layer, which in turn is covered by a thin blanket of unconsolidated sediments. Recovered sediments include: lumps of a buff-colored foraminiferal ooze (Core IB), Pliocene in age and of Trubi facies (Baldacci, 1886); and a piece of late Quaternary marl ooze (Core $3 \mathrm{~B}$ ) which may be representative of this superficial unconsolidated blanket. In any case, they suggest that pelagic sediments were deposited during the Pliocene and the Quaternary at or near this site.

\section{The Hellenic Trough (Site 127)}

In the deep trench, situated at the foot of the Hellenic Arc, the first hole of Site 127 penetrated 437 meters of turbidites before reaching blocks of Cretaceous dolomites. A thin layer $(0.75 \mathrm{~m})$ of Pliocene pelagic marl ooze was intercalated between two dolomite blocks.

The Pliocene ooze, plastic and light gray in color, displays faint subhorizontal bedding and hydrotroilite 
spots. Its calcium carbonate content is 62 per cent, mainly nannoplankton. Pelagic sedimentation was evidently active in this area during the Pliocene.

The Nile Cone (Sites 130 and 131)

Holes were drilled on the deep Nile Cone (Site 131) and on the Mediterranean Ridge (Site 130) which proved to be a compressional feature comprising a part of the Nile abyssal plain.

At both sites, thin pelagic layers are interbedded with Nile turbidites (Figure 6). The pelagic beds are lightcolored, olive gray marl oozes. Their calcium carbonate content is high, 50 to 75 per cent, consisting of nannoplankton and foraminifera. The beds are generally thin, 5 to $10 \mathrm{~cm}$, but occasionally reach several meters (Site 130, Core 6 ). The upper part of the beds show burrowing and the top is often eroded. The pelagics are easy to distinguish from the Nile turbidite beds, which are dark gray to black and comprise coarse sands grading to clays (5\% calcium carbonate).

At Site 130, the upper part of the sedimentary column, from the sea bed surface down to 14.5 meters consists of pelagic marls only. They are of the same lithology as the interbedded pelagic layers. In addition, they are bedded with sharp boundaries. Burrowing and hydrotroilite spots are abundant.

The pelagics interbedded with the Nile turbidites suggest that occasionally pelagic sedimentation took place between two turbidity flows from the Nile. Often the flows were too close in time to allow thick pelagic sediments to accumulate. The small amounts that were deposited were eroded by the next flow. However, this rapid succession of turbidites was occasionally interrupted. Taking an approximate rate of $3 \mathrm{~cm} / 10^{3} \mathrm{y}$ for the pelagics, the gap is estimated to be between 1000 and 10,000 years, during which time no turbidites reached Site 130.

Finally, toward the middle of the Quaternary, uplift isolated Site 130 from the turbidity flows, and the top blanket of pelagic oozes was deposited.

\section{TURBIDITES AND GRAIN FLOW DEPOSITS}

Our drilling penetrated many areas of turbidity current and grain flow deposits, as may be expected for a sea surrounded by continents.

The more important accumulations are the Nile Cone (Site 130,131) and the infill of the Hellenic Trough (Sites 127 and 128).

However, turbidites are also present in small basins adjacent to land, as in the Alboran Sea (Site 121), the Valencia Gulf (site 122, 133) and even the cleft opened in the Mediterranean Ridge (Site 126). No turbidites were noted in the only Atlantic site (120) of the Leg.

\section{The Alboran Basin Turbidites (Site 121)}

Turbidites were drilled at Site 121, between 290 and 670 meters. At the base they are Pliocene in age and lie unconformably on Tortonian marls. The upper beds are of Calabrian age (Figure 4).

They consist of sequences of quartzose sands grading to marl oozes. The sands are terrigenous, containing quartz, feldspar, mica, and only 3 to 5 per cent bioclastics. The marl oozes are also mainly land derived detritus (70 per cent fine terrigenous debris) together with nannoplankton and foraminifera.

Sequential analysis (Bouma, 1962; Nesteroff, 1962) was difficult due to poor recovery. However, the lower limits of the sequences are always sharp, while the passage from silt to clay is either gradational or sharp. Altogether, the sequences are generally well graded and are similar to piston-cored recent turbidites.

Since the Alboran Basin is surrounded by land, it is surprising that turbidites occur only in the Pliocene and

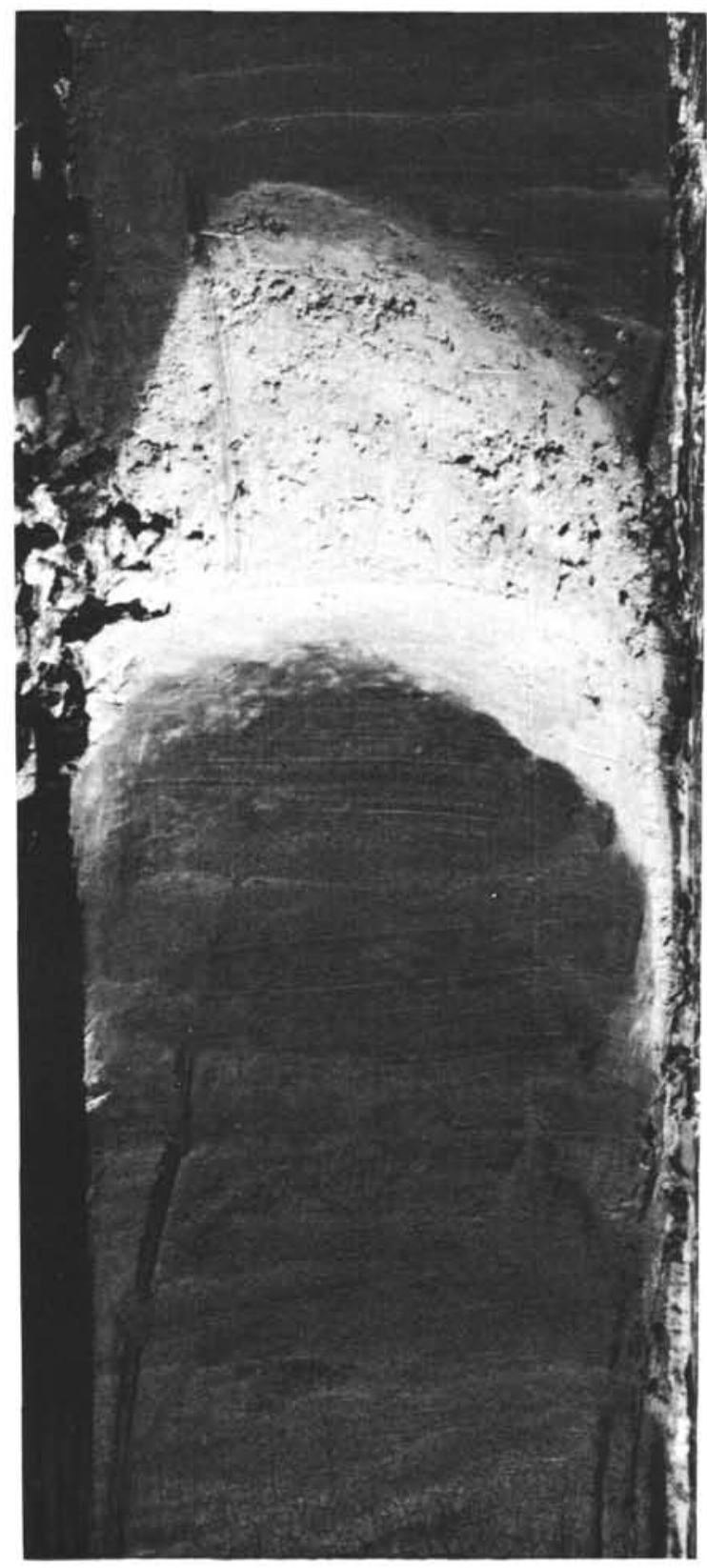

Figure 6. Mud clasts embedded in the coarse sand of a Nile turbidite proximal sequence. Note the flattened bottom of the lower clasts (131-1-6, $40-50 \mathrm{~cm}$, on scale. 
Calabrian. However, the present topography of the bottom, consisting of separated basins, suggests a tectonic control. During the Tortonian, shortly after the opening of the Alboran sea, only a few turbidites could reach the central position of the site. The Pliocene orogeny modified the topography and a period of turbidite deposition followed. Later, at the end of the Calabrian, new tectonic events isolated Site 121 from turbidity current activity. Hemipelagic sedimentation then resumed.

\section{The Valencia Basin Turbidites (Sites 122, 123)}

The two holes drilled in the Valencia Gulf first encountered a thick series of turbidites (Figure 7). At Site 122 , located in a deep-sea canyon, 160 meters of Quaternary and Pliocene turbidites and contourites were penetrated before reaching the Messinian evaporites. The rhythmic sequences are thin and contain quartzose sand grading to silt and marl ooze (turbidites, Bouma, 1962; Nesteroff, 1962). They are interbedded with layers of marl ooze with millimetric sand-silt laminae (contourites, Hollister 1967). An important hiatus, estimated at one million years, separates Pliocene and Quaternary turbidites. At the base of the turbidites, a horizon of gravel was encountered which plugged the drill pipe. This plug included gravels of basalt and gypsum, together with rare limestone and shallow-water shell fragments.

Interpretation of the sedimentary column at Site 122 is difficult. The gravel is of unusual composition and can be interpreted as a mixing of different strata penetrated by the drill string. An alternative is that this gravel resulted from erosion of a sea bed older than Pliocene (see discussion in Chapter 4).

The Pliocene-Quaternary unconformity (Figure 10) suggests that the initial cutting of the Valencia channel system occured between the Upper Pliocene and the Middle Quaternary.

At Site 123, positioned on the slope of a buried volcano, 2685 meters of turbidites and contourites overlie a thick body of ash. The rhythmic sequences are mainly composed of terrigenous turbidites (similar to those of Site 122) grading from quartzose sands to marl oozes together with rare interbedded contourite layers. A bed of gravel, composed of basalt, quartz, sandstone and shallow-water shells, occurs just above the Pliocene-Quaternary boundary.

In conclusion, turbidity currents were active in the Valencia Gulf after submergence in the Pliocene. Beds of basaltic gravel suggest that erosion of the basaltic acoustic basement took place before its burial under sediments (see discussion in Chapter 5).

\section{Balearic Basin Turbidites (Site 124)}

Site 124 is located on the rise near the foot of the continental margin of the Balearic block (Figures 18 and 19). Here 350 meters of turbidites and contourites were penetrated before the drill string entered Messinian evaporites.

These rhythmic deposits of Pliocene and Quaternary age are comprised, in the lower half, of interbedded light- and dark-colored marl oozes. Sharp contacts separate the beds and quartzose sand-silt laminae occur at the base of the dark gray oozes. Both types of marl oozes are interpreted as contour current deposits.
The upper part of the rhythmic deposits is mainly composed of graded terrigenous sand-silt/marl ooze sequences and interpreted as turbidites.

This accumulation of deposits indicates that the foot of the Balearic margin has been formed since the Pliocene, first by sediments deposited by contour currents, and later dominantly by turbidites.

\section{The Ionian Basin Turbidites (Site 126)}

Presently, the Mediterranean Ridge is an area of hemipelagic deposits. However, the deep longitudinal cleft opened in the Ridge is filled with turbidites and at Site 126, positioned in this cleft, drilling first penetrated 106 meters of Quaternary turbidites before reaching middle Miocene marls.

The Quaternary fill of the cleft contains both turbidites and contourites. The former are graded sequences of foraminiferal sand-silt/marl ooze. The contourites are sequences, 30 to $50 \mathrm{~cm}$ thick, of marl ooze interbedded with sharp boundaries and having laminae of foraminiferal sand. Turbidites are dominant in all cores.

Layers of redeposited sapropels are also interbedded as common turbidite sequences with pieces of dolomitic ooze embedded in them. These probably occur as slumped rocks from the Messinian evaporitic series which are dissected by the cleft.

\section{The Hellenic Trough Turbidites (Sites 127 and 128)}

A deep elongate trough follows the foot of the Hellenic Arc between the Peloponese and Crete. Two sites, 127 and 128 , were positioned on a north-south transect of the fill of this trough. Both penetrated thick series of Quaternary turbidites and contourites. The northern sites (127), located almost at the foot of the continental slope of the Arc, bottomed in hard rock below 437 meters of turbidites, while the southern one (Site 128) was abandoned at 475 meters, still in Quaternary turbidites. At both sites, the very high sediment accumulation rates reflect the turbidity and contour current emplacements of the trench fill.

A good biostratigraphic and lithologic correlation was established between the two sites (see Chapter 9, Figures 15 and 16). Broadly speaking, two lithologic units were identified. The lower is comprised of dominantly marl oozes, with occasional terrigenous sand-silt interbeds. These are relatively low energy deposits and they are interpreted as contourites. The upper contains numerous graded terrigenous sand-silt/marl ooze sequences, typical of high energy deposits, and are interpreted as turbidites. There are two periods during which sapropels were redeposited with the turbidites or the contourites. They permitted a finer subdivision of the sedimentary columns into lithological units (see Chapter 9).

This lithological succession suggests that the Quaternary fill of the trench was emplaced by currents of increasing energy. It reflects the gradual infill of the trench. At first only contourites were able to reach the area. Later, when the basins situated between the sites and the sources became filled, turbidites were able, in turn, to reach this area. This progression is similar to the first stages of the filling of a flysch trench. Actually the phase of turbidite deposition is probably correspondent with the first phase of compressional deformation. Because of this compression, 


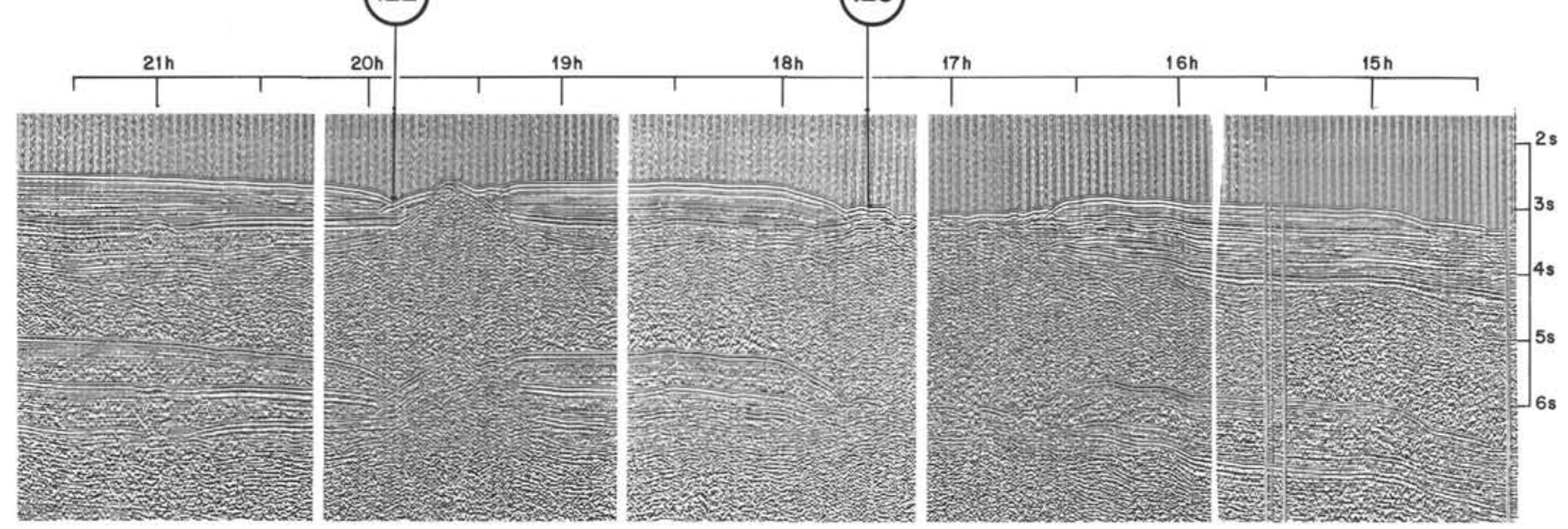

Figure 7. Lithologic classification of the turbidite sand layers of the Hellenic Trench drillings (coarser than $62.5 \mu$ fraction). The two Sites, 127 and 128, are not very different. The field was estimated with the smear slides.

POLYMEDE (Charcot COB) 16/5/1970



Figure 8. Oblique bedding in a core of the Strabo Mountains suggesting sliding or tectonic deformation of the area (129A-3-1, $25 \mathrm{~cm}$, on scale). 


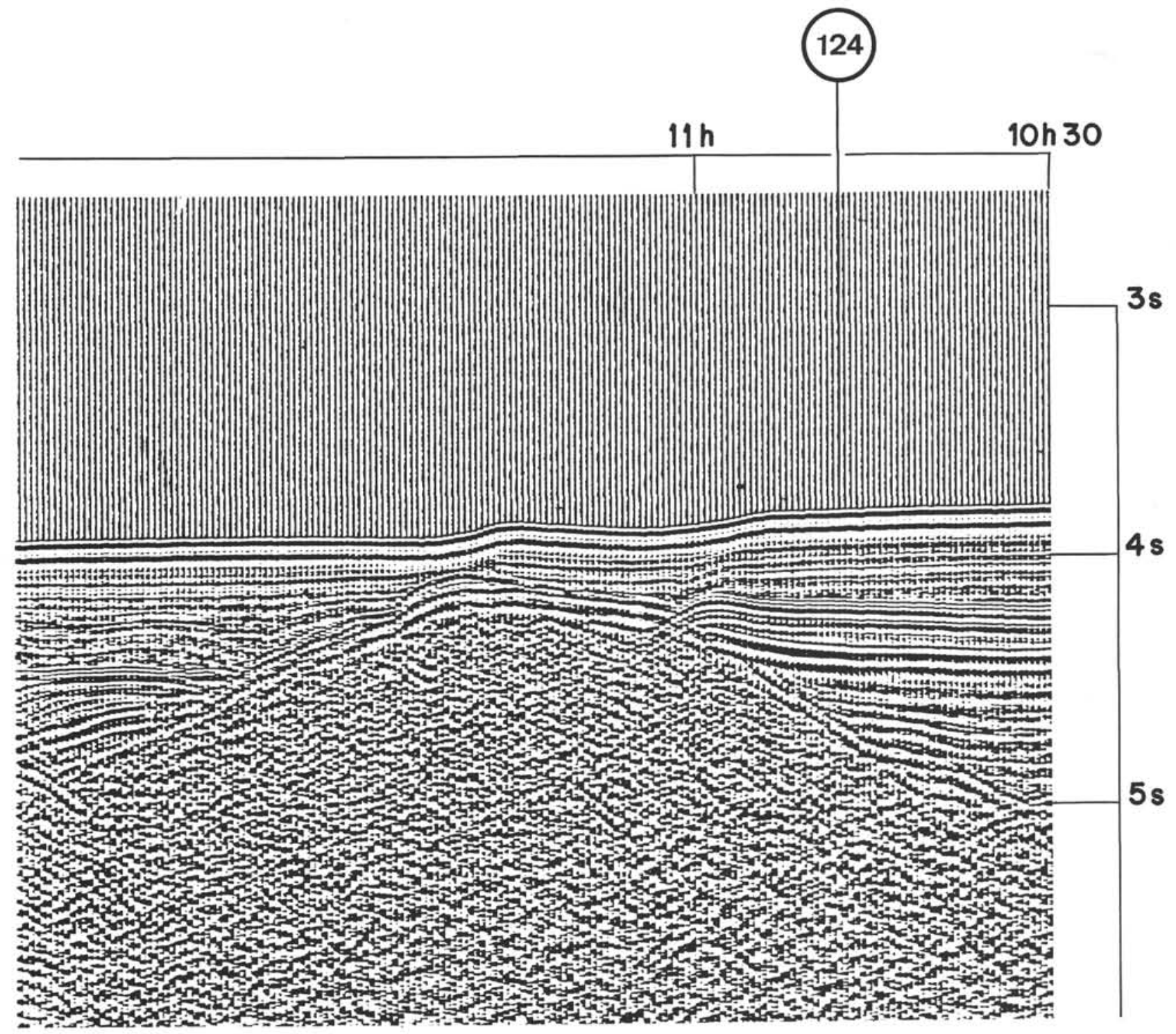

Figure 9. Gravel embedded in a pelagic marl ooze, a meter above the Plio-Miocene unconformity in Site 134, off the subsided Sardinian margin. The gravel, mainly well rounded, is probably fluviatile in origin signifying the proximity of the land $(134-7-5,20-25 \mathrm{~cm}$, on scale).

the rising areas provide the frequent greywacke detritus and the slope for the turbidity currents (Figure 10, a triangular plot of the 127 and 128 sands).

The correlation of data from Sites 127 and 128 pointed to a noticeable thickening of the lithological units towards this trench wall. As the sedimentary filling of the trench is flat, indicating a supply by longitudinal transport, this suggests a slight subsidence along the northern margin of the trench which could be related to a subduction plane. The possible existence of a Benioff zone is also indicated by the presence of glaucophane in the sands of Site 128 (1-2, $88 \mathrm{~cm} ; 1-2,142 \mathrm{~cm} ; 4-3,4 \mathrm{~cm} ; 4-3,90 \mathrm{~cm})$ and Site 127 $(7-5,134 \mathrm{~cm})$. It was known that this interesting mineral develops under high-pressure/low-temperature regional metamorphism. These conditions are developed by differential movement between the descending ocean floor and the overlying lithospheric plate. Therefore, the dolomite and limestone blocks (early Cretaceous) of Site 127 may be interpreted as masses of a mélange deposit, tectonically deformed.

\section{The Nile Cone Turbidites and Grain Flow Deposits}

Two sites were positioned on the submerged Nile Cone. The first, Site 131, is at the foot of the Cone, near the abyssal plain. The second, Site 130 , is on the Mediterranean Ridge, which is a part of an older Nile abyssal plain, presently compressed and uplifted by the subduction beneath the Hellenic Arc of the lithospheric plate on which it lies.

Almost all the sediments of the Nile Cone are turbidites and grain flow deposits. However, rare but very distinctive pelagic layers are occasionally interbedded with turbidites. In addition, at Site 130, pelagic oozes cover the turbiditic series (see pelagic deposits, this chapter). The petrography 


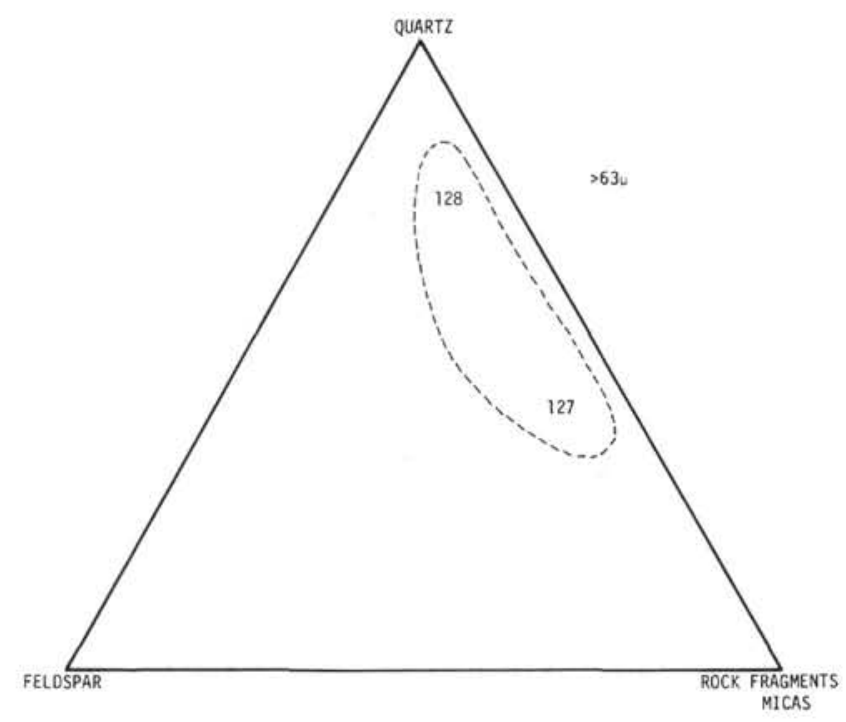

Figure 10. The Valencia Gulf; reflection profile (SW-NE) across Sites 122 and 123 (R/V Charcot, cruise Polymede I). Note the basement peak near Site 122 and the great thickness of sediments. All the Quaternary and Pliocene deposits penetrated were contourites and turbidites. At Site 122, Messinian marls with gypsum formed the $M$ Reflector. At Site 123, the drilling bottomed in a thick accumulation of ash.

of turbidites is similar at both sites but the sedimentary structures are different and reflect the position of the cores in the general setting of this deep-sea fan.

\section{Site 131}

At Site 131, at the foot of the fan, 272 meters of turbidites and grain flow deposits were penetrated. The upper part of the sedimentary column contains thick sequences ( 2 to $2.5 \mathrm{~m}$ ) of coarse dark sand topped by a thin layer of black clay. The sands are characterized by (1) great thickness $(2.5-3 \mathrm{~m}),(2)$ lack of internal sedimentary structures (e.g. graded bedding, parallel or convolute lamination, etc..), (3) presence of mud intraclasts, and (4) sharp upper and lower surfaces.

The clay partings making up the top of the sequences are very thin, some few centimeters. They contain clay minerals, dominantly montmorillonite, quartz, and occasionally pyrite. The calcium carbonate content is very low, 1 to 5 per cent.

The mud intraclasts are scattered throughout the sand beds and only occur as a concentrated horizon in Core 131-1-6 (Figure 11).

The textural and structural characteristics suggest that the emplacing flows were capable of remarkable erosive power (clay fragments, sharp erosive surfaces, etc.). The relative coarseness and consituent mollusc tests also point out the proximal nature of these deposits.

This sedimentary assemblage is very similar to Africanderived coarse sandstones which are supposed to belong to an early Miocene clastic wedge (Numidian continental rise

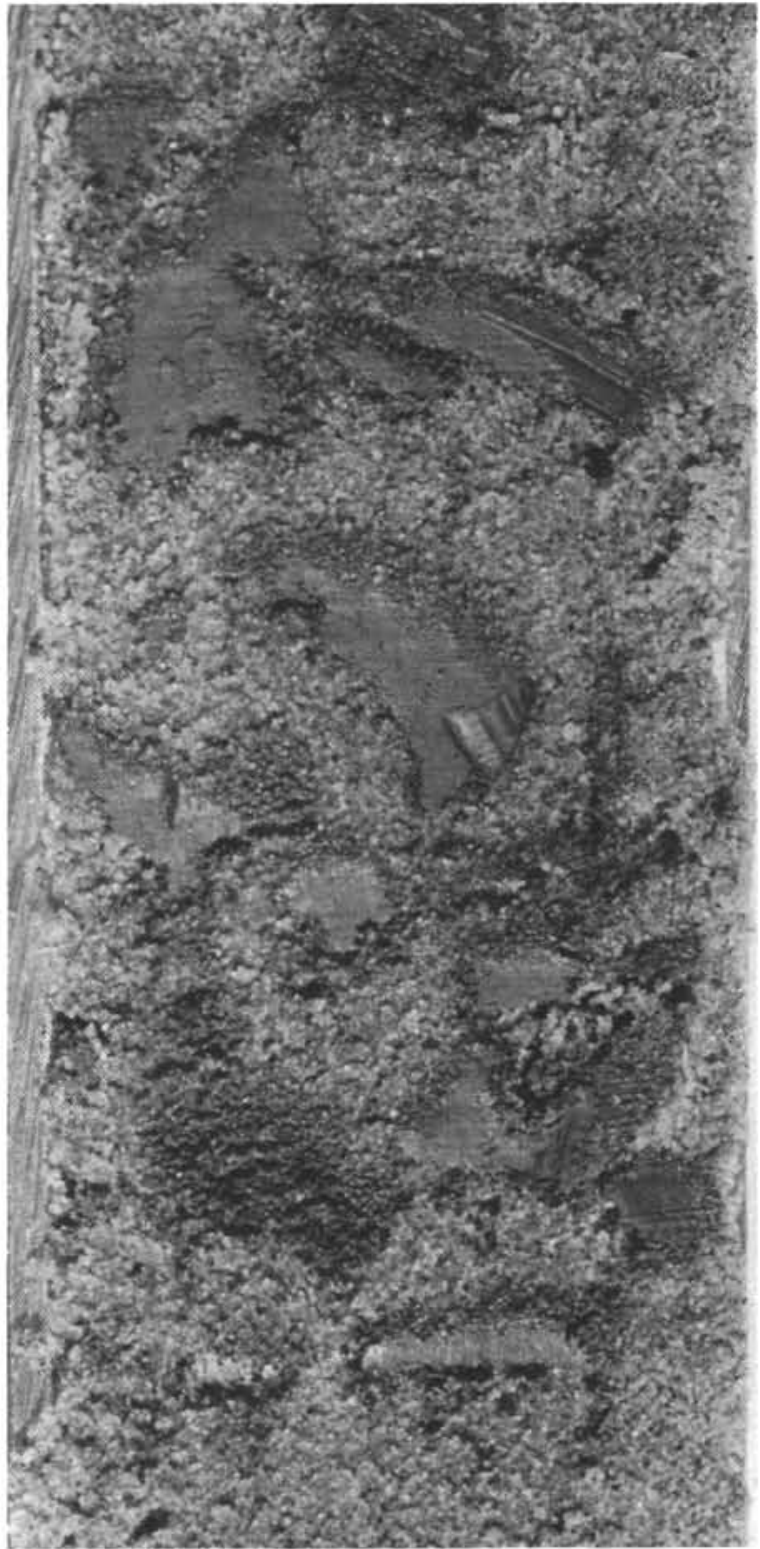

Figure 11. Origin and emplacement of Site 132 ash layers as suggested by the geological trends of volcanic rocks from south Italy (modified from Civetta et al, 1970).

in the western Mediterranean) and called Facies I deposits by Wezel (1970). From a sedimentologic point of view, these sediments of Facies I belong to the same family of the fluxoturbidites of the Carpathians (Dzulyinski et al., 1959), i.e. are medial between slumps and turbidites.

Unfortunately, these fluxoturbidite sandstones were originally poorly described and not sufficientely documented, so a great deal of confusion existed in the literature. From a genetic point of view too, such deposits are not completely understood, nor is their relationship to turbidity current sediments (i.e., turbidites) yet clear. 
By comparison with the Facies I sandstones, we can interpret the Nile sandstones as emplaced by a resedimentation mechanism, such as bottom gravity flows moving over the floor of the canyon or of the fan channels and depositing their load as sheets in a fan.

In conclusion, the Pleistocene coarse sublithic sands of Cores 131 and $131 \mathrm{~A}$ are inferred to be proximal deposits belonging to the Nile submarine fan.

The lower part of the sedimentary column of Site 131 contains shorter sequences ( 20 to $50 \mathrm{~cm}$ ) mainly composed of black clays with a normal thick layer of basal sand.

\section{Site 130}

At Site 130 , on the ridge, rhythmic deposits were penetrated between 14.5 and 563 meters. They comprise even shorter sequences $(10-30 \mathrm{~cm})$ of black clay with a lamina or a thin layer of sand at the base. Thus the clay-dominated sequences of Site 130 show a distal facies while the 131 series display a generally coarser, more proximal facies with the characteristic succession of a prograding fan: coarse sand sequences overlying finegrained ones. The observed thinning of the beds from Site 131 to Site 130 supports the idea of a typical "clastic wedge".

The average grain size is finer at Site 130 than in $131 .{ }^{1}$ The samples from Site 131 are mostly sands with a lutite content ranging from 2 to 40 per cent. It is noteworthy that samples with a median grain size over 200 microns contain a lutite percentage which is sometimes as high as 20 and even 30 per cent. Some samples of Site 131 and all four samples studied from Site 130 are classified as lutites (more than $50 \%$ grain size finer than 60 microns).

At Site 131, the sorting ranges from 0.6 to 3.2 (moderately to very poorly sorted).

The heavy fraction of sediments from Sites 130 and 131 contains a remarkable quantity of augite, epidote, and green hornblende. Augite and epidote are slightly more frequent at Site 131, and hornblende prevails in the only available heavy fraction sample of Site 130 (Core 4-2-113). Garnet, (mostly almandine), tourmaline, zircon, apatite, clinozoisite, biotite, and chlorite are also present in minor quantities. Clino- and orthopyroxenes (such as bronzite and hypersthene) have been observed in a few cases in both sites. Magnetite and other opaque minerals make up about one third of the heavy fraction at Site 131. They are less frequent at Site 130.

In conclusion, the suggested source of the turbidites is the Nile River, as indicated by rounded and frosted quartz grains, the association of hornblende and epidote, and the dominant montmorillonite in the clays.

\section{Occasional Turbidites on the Sardinian Margin}

The presence of turbidity current deposits were suggested in the sites located on the Sardinian margin (Sites 133 and 134). At Site 133, washed sand was found at the top of Core 1 and, below, pebbles were interbedded with

\footnotetext{
${ }^{1}$ Textural and mineralogical observation carried out in collaboration with C. Bartolini, P. Malesani, and P. Manetti.
}

pelagic marl oozes. In the holes of Site 134, gravels and pebbles were embedded in pelagic oozes.

\section{SLUMPED AND TECTONICALLY AFFECTED DEPOSITS}

Slumped rocks, pebbles, gravels and evidence of folding were encountered in certain of our sites which were generally situated in tectonically affected areas.

On Gorringe Bank (Site 120), Cores 4 and 5 (Unit 4) show angular brecciated fragments in slump structures. These cores are of lower Cretaceous age and indicate slump activity during this period.

On the Sardinian margin, the basal Pliocene pelagic oozes which unconformably overlie the evaporitic series contain numerous well-rounded gravels (Site 134, Cores 6 and 7, see Figure 12). In addition, they are folded. Higher in the sedimentary column, the Quaternary pelagic oozes contain pebbles of basement rock (Site 134, Core 2; Site 133, Core 1). This folding, together with the occurence of coarse material, reflects the tectonic activity of the Sardinian margin from the beginning of the Pliocene throughout the Quaternary.

In the Ionian Sea, a deep cleft opens in the Mediterranean Ridge. The Quaternary turbidite and countourite



Figure 12. Balearic block, southeastern margin; reflection profile (E-W) and position of Site 124 $(R / V$ Charcot, cruise Polymede I). Note the peak of the basement near the site, the thick accumulation of sediments on the margin and the salt diapirs under the abyssal plain. 
infill of this cleft contains pebbles of dolomitic ooze, probably of Messinian age (Site 126, Core 2), fallen or eroded away from the wall of the cleft, which has exposed the Serravalian.

The southern slope of the Hellenic Arc was investigated in two zones. Both contained tectonically disturbed material which could be interpreted either as slump or mélanges. In the Hellenic Trough, drilling beneath the Quaternary infill reached large limestone and dolomite blocks of lower Cretaceous age (Site 127, Cores 16, 17, 18, $4 \mathrm{~A}, 5 \mathrm{~A}$, and 1B). The rocks were deposited on top of a 45 degree slope. Below these, in the original hole, the drill reached a layer of Pliocene pelagic ooze and bottomed in a second dolomitic rock (Site 127, Cores 18 and 19, see Chapter 9.

In the more eastern section of the Arc, on the southern slope of the Strabo Mountain (Site 129), a confused sequence of pelagic oozes of middle and late Miocene age and fragments of younger rocks were recovered (Figure 13). Some of the cores are folded or deformed while others remained undisturbed. Here again we may be dealing either with slumps or with a tectonically compressed series along a subduction zone.

\section{VOLCANIC DEPOSITS}

During the Neogene, volcanic activity occurred in many places in the Mediterranean, and some volcanos are still active today. Consequently it is surprising that Leg 13 drilling penetrated only a few ash deposits. The largest is a thick body of ash, probably the slope accumulation of a volcano located in the Valencia Gulf (Site 123). All the other occurrences are thin layers of volcanic glass interbedded with other types of deposits, mainly pelagics and turbidites.

\section{Valencia Gulf Volcanism (Site 123)}

Site 123, located on the flank of a buried basement peak, penetrated 268.5 meters of Pliocene and Quaternary turbidites and a thick body of volcanic ash. The hole was abandoned at 398 meters without reaching the base of the ash layer (Figure 10).

The deposit is composed exclusively of colorless shards of volcanic glass which are rich in gaseous and liquid inclusions. The larger fragments reach $0.5 \mathrm{~mm}$. Small amounts of feldspar, light micas, and clays are present with the glass shards. The shards are loosely consolidated, with only a few lithified layers encountered at random horizons. The index of refraction of the glass is 1.55 , which classifies it as andesitic or dacitic ash.

This type of deposit is generally produced by violent subaerial eruptions, such as that of Somma-Vesuvius. The thickness (more than $120 \mathrm{~m}$ ) of the accumulation and the total lack of marine fauna also suggest that the Site 123 ash is not a thick marine tephra layer, but rather a flank deposit of a subaerial volcanic cone.

$\mathrm{K} / \mathrm{Ar}$ dating of this ash showed an age of about 23 my (see Chapter 5).

\section{Tyrrhenian Sea Volcanism}

At Site 132, located in the Tyrrhenian sea, about thirty ash layers were seen, of which nine main layers were noted in the Quaternary section. None were observed in the Pliocene sequence.

The tephra layers are generally thin $(3-5 \mathrm{~cm})$, but a 20 cm-thick graded layer occurs in Core 1, Section 3. The tuffaceous deposits are nearly always mixed with foraminiferal mud. It is supposed that the volcanic particles have been blown directly from the volcano in the Tyrrhenian Basin and incorporated into the sediment by the action of submarine currents. The observed succession probably does not represent the original stratigraphic sequence. The sedimentary mixture of ash with mud prevents mineralogical and petrochemical study of the bulk of the tephra layers. Furthermore, because of submarine weathering (halmyrolysis) of the volcanic glass, it is not useful to give information on the parent magmas.

In spite of these shortcomings, some information about the source of the Tyrrhenian ash layers was obtained from qualitative mineralogical observation and chemical analysis of some relatively fresh material. Because of the constant presence of sanidine and biotite in the tephra (Tables 1 and 2 ), we are inclined to believe that the volcanicity was of trachytic type, similar to that of Quaternary Campania volcanos (Island of Ischia-second cycle, Phlagraean Fields and Somma-Vesuvius, see Figure 14). Compared with the trachytes erupted from the Campania volcanos, the ash

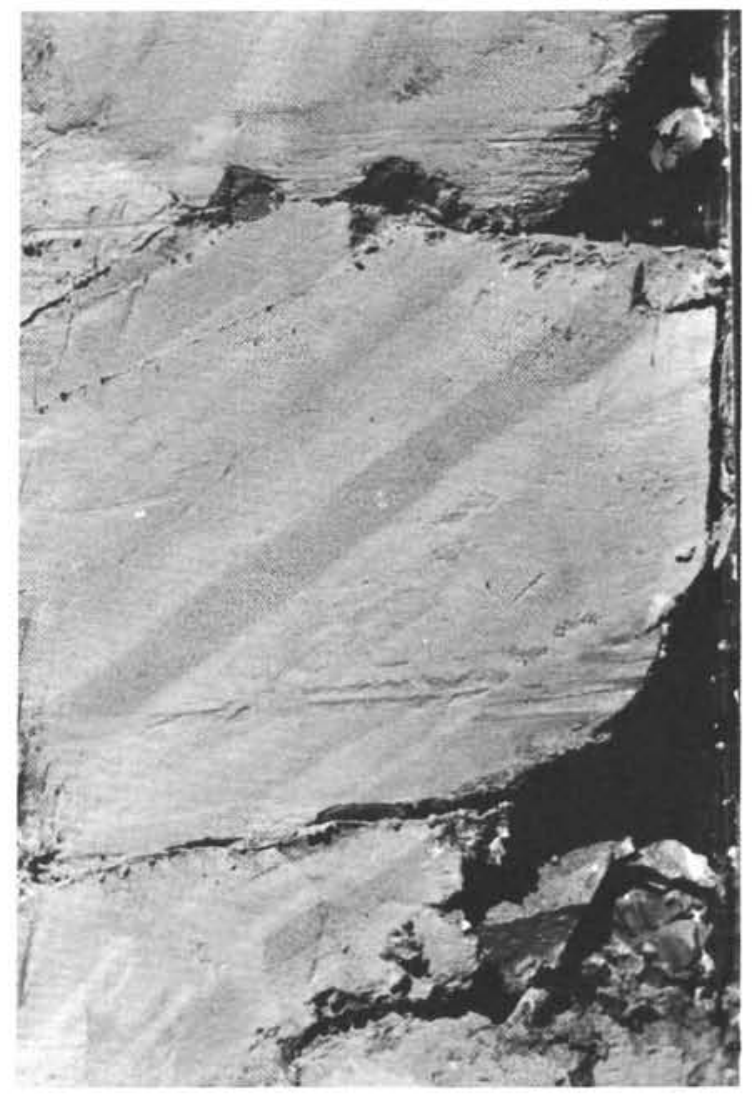

Figure 13.. Balearic Basin; detailed reflection profile (W-E) across Site 124 (R/V Charcot cruise Polymede I). Note the thick accumulation of Quaternary and Pliocene turbidites above Reflector $M$. Below Reflector $M$ the evaporitic series comprises dolomitic marl interbedded with anhydrite. 
TABLE 1

Important Minerals in some Tyrrhenian Ash Layers-Site 132

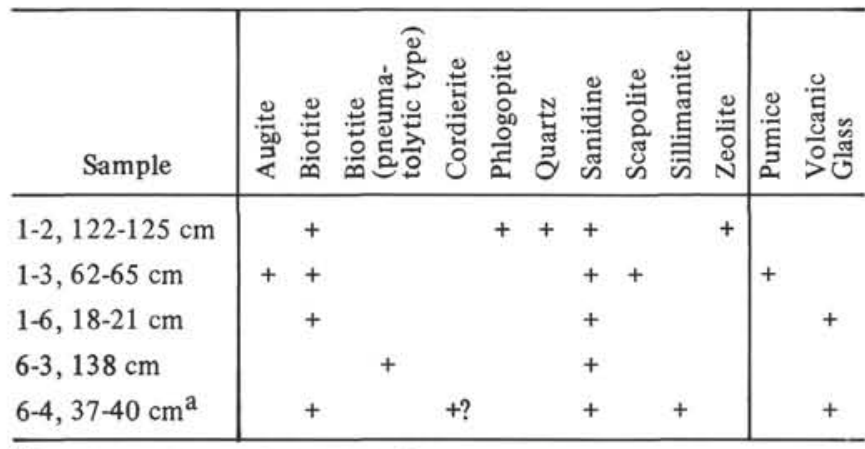

${ }^{\mathrm{a}}$ See chemical analysis in Table 2

TABLE 2

Chemical Analysis of Two Tephra Layers ${ }^{\mathrm{a}}$

\begin{tabular}{l|c|r}
\cline { 2 - 3 } & \multicolumn{2}{c}{ Sample } \\
\cline { 2 - 3 } & $\begin{array}{c}132-1-3, \\
62-65 \mathrm{~cm}\end{array}$ & $\begin{array}{r}132-6-4 \\
37-40 \mathrm{~cm}\end{array}$ \\
\hline $\mathrm{SiO}_{2}$ & 43.62 & 27.70 \\
$\mathrm{Al}_{2} \mathrm{O}_{3}$ & 15.29 & 10.57 \\
$\mathrm{Fe}_{2} \mathrm{O}_{3}$ & 3.54 & 3.17 \\
$\mathrm{FeO}$ & 0.48 & 0.42 \\
$\mathrm{MnO}$ & 0.09 & 0.17 \\
$\mathrm{MgO}$ & 2.11 & 2.11 \\
$\mathrm{CaO}$ & 9.11 & 24.53 \\
$\mathrm{Na}_{2} \mathrm{O}$ & 4.22 & 2.10 \\
$\mathrm{~K}_{2} \mathrm{O}$ & 5.10 & 2.30 \\
$\mathrm{TiO}_{2}$ & 0.80 & 0.75 \\
$\mathrm{P}_{2} \mathrm{O}_{5}$ & 0.36 & 0.36 \\
$\mathrm{H}_{2} \mathrm{O}-$ & 2.70 & 2.35 \\
$\mathrm{P}$. C. & 11.75 & 23.23 \\
\hline Total & 99.17 & 99.70 \\
\hline a Conducted in Istituto Internazionale de \\
Vulcanologia of Italian C.N.R., Catania, \\
Italy. Courtesy of Professor A. Rittmann \\
and Dr. R. Romano.
\end{tabular}

layers show a lower $\mathrm{SiO}_{2}$ content. This is probably due to submarine weathering of the material, as is substantiated by the high percentage of $\mathrm{CaO}$ and P.C. $\left(\mathrm{H}_{2} \mathrm{O}, \mathrm{CO}_{2}\right.$, etc. $)$ in the two analyses.

Rittman, ${ }^{2}$ who kindly examined the samples, estimates (with a probability of $80-90 \%$ ) that the ash originated in the Phlaegrean Fields (Figure 11). The argument is that its $\mathrm{SiO}_{2} / \mathrm{Al}_{2} \mathrm{O}_{3}$ ratio is 2.6 to 2.8. Phlaegrean Fields ash ratios range from 2.5 to 3.0 , Ischia from 2.9 to 3.4 , and early Somma-Vesuvius is about 3.2.

K/Ar dating reported by Civetta et al. (1970) showed that the early pyroclastic activity of Phlegraean Fields and Somma-Vesuvius are roughly contemporaneous and began in the late Quaternary (about $0.2 \mathrm{my}$ ). The lavas and pyroclastics of the second cycle of activity of the island of Ischia erupted a little earlier, about 0.3 my.

\footnotetext{
${ }^{2}$ Istituto Internazionale di Vulcanologia-Catania, Italy.
}

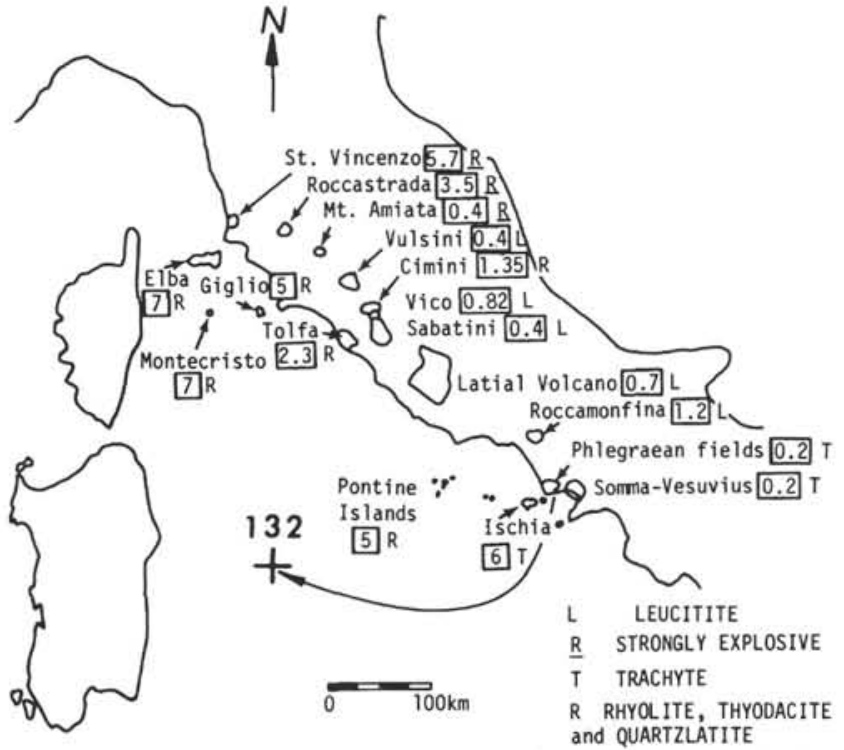

Figure 14. Messinian evaporitic series. Massive anhydrite with chicken-wire structure. Balearic Basin (124-13-2, 40 $\mathrm{cm}$, on scale).

The other Italian volcanos are unlikely as sources of Site 132 tephra because:

1) Etna activity, essentially effusive, produced little volcanic ejecta (only locally);

2) Roccamonfina and Latial volcanos produced leucititic volcanics;

3) Pontine Islands and Roccastrada volcanos were active in Pliocene time and produced rhyolotic and rhyodacitic ignimbrites.

\section{Occasional Ash Layers}

Isolated or small groups of ash layers were present in practically all sites. In the Balearic Basin, at Site 134, some ash shards are mixed with the sand and gravel of Core 2, Quaternary in age. On the Mediterranean Ridge, at Site 125 in the Ionian Basin, drilling penetrated a single thin brown layer of ash in Core 1, Section 4, upper Quaternary in age.

In the Hellenic Trough, at Site 127, a single layer of mixed ash shards and foraminifera was observed in the upper lithologic unit, Quaternary in age.

As opposed to the Nile Cone, on the Mediterranean Ridge a single thin layer of ash was encountered in the superficial pelagic blanket of Quaternary age.

\section{EVAPORITIC SERIES}

Evaporitic deposits of Messinian age were recovered in both eastern and western basins. These results, together with known seismic data concerning the geographic distribution of deep-sea diapirs, suggest that a continuous evaporite formation was deposited in the entire Mediterranean Sea during the Messinian. For detailed petrography and mineralogy, see Chapters 21 and 22 . Two possible models of deposition are discussed in Chapters 21, 43, and 44.1.

In the western basin, the evaporitic series was encountered in almost all sites: 122, 124, 134, and 132 . The exceptions are Sites 121, 123, and 133. In the Alboran 
Sea (Site 121), the Messinian is missing because either the evaporites were not deposited in this area or they have been since eroded (see Chapters 3 and 49.3). On the Valencia Ridge (Site 123), the Messinian is also missing, probably because of erosion. At the last site, 133, on the Sardinian margin, continental deposits, probably a lateral equivalent of the evaporites, underlie Quaternary marl oozes.

In the sites where the evaporites are present, drilling generally penetrated the upper part of the formation before being stopped by hardness of the rocks. Thus, in the Valencia Trough (Site 122), slightly dolomitic marls containing large lenses of gypsum were cored. In the Balearic Basin, in the two sites (124 and 134) situated on its western and eastern margins, dolomitic marls and dolomitic oozes were first cored and frequently contain large gypsum crystals (Figure 15). These overlie massive beds of salt and anhydrite at Site 124, and Site 134 overlie anhydrite and halite, interbedded with dolomitic oozes which enclose remains of marine microfauna (Figure 16 and 17). In the Tyrrhenian Sea (Site 132), a similar sequence was drilled, that is, dolomitic marls with gypsum crystals above beds of solid gypsum interbedded with dolomitic oozes (Figures 17 and 18).

In the eastern basin, the Messinian evaporitic series was cored at Sites 125, 126, and 129. On the deep Mediterranean Ridge, and in the Ionian Sea (Site 125), dolomitic oozes overlie a horizon of massive gypsum. In the same vicinity, at Site 126, which was drilled in a cleft of the ridge, only slumped pieces of similar dolomitic oozes were recovered, embedded in Quaternary turbidites. Finally, at Site 129 , positioned to the east between the ridge and Strabo Mountain, the lower part of the Messinian was cored. There the dolomitic oozes contain ostracods and benthonic foraminifera indicating brackish-water conditions.

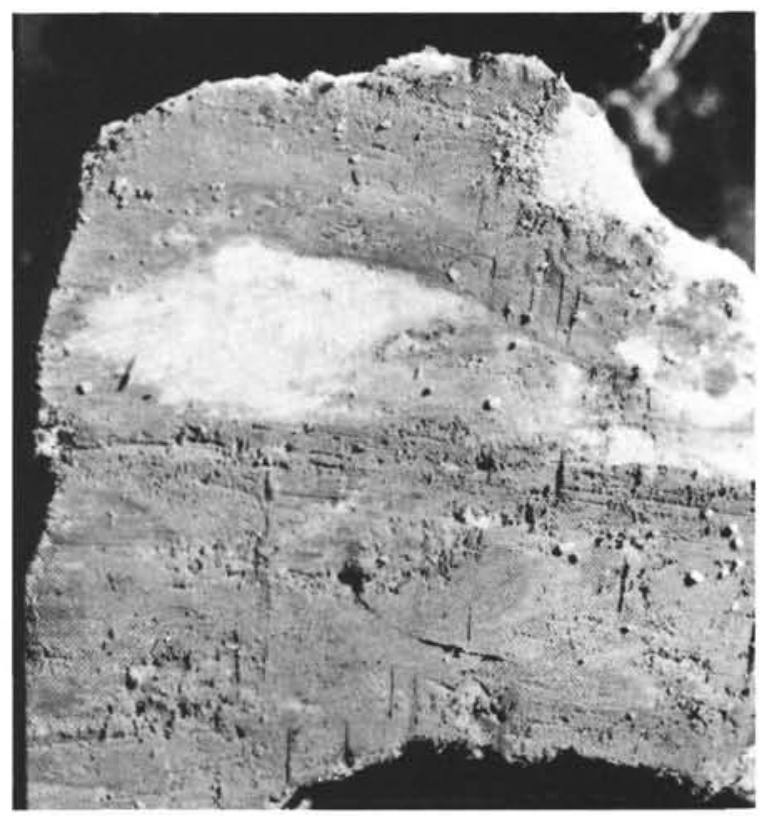

Figure 15. Messinian evaporitic series. Massive transluscent halite with millimetric interbed of anhydrite. Balearic Abyssal Plain near the Sardinian margin (134-10-2, on scale).



Figure 16. Messinian evaporitic series. Massive gypsum with undulated laminations suggesting stromatolites. Tyrrhenian Sea (132-27-2, $105 \mathrm{~cm}$ on scale).

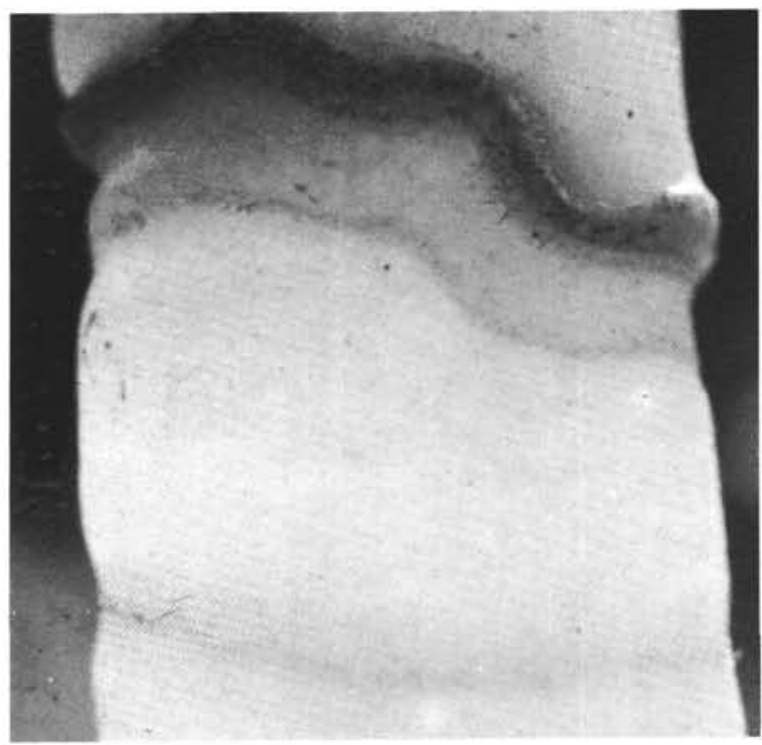

Figure 17. Messinian evaporitic series on the Sardinian margin. Development of large nodules of saccharoidal gypsum in a marl ooze horizon (134-D-1-1, on scale). 




Figure 18. Subsided Sardinian margin; reflection profile (W-E) showing the position of Sites 133 and 134 (R/V Charcot, cruise Polymede I). At Site 133 pelagic Quaternary oozes overlie continental arenites. Site 134 was implanted above the edge of the Balearic Abyssal Plain characterized by salt diapir structures.

Detailed studies (see Site chapters, and Chapters 21 and 22) indicate the following petrographic characteristics of the evaporites: (a) laminated and nodular (chicken-wire) structures, (b) wavy laminations indicative of stromatolites (e.g., Figure 19), (c) admixtures of coarse terrigenous sands, (d) conglomerate horizons, and (e) large gypsum crystals isolated in dolomitic marls, etc.

Other data, such as the shallow-water fauna of the interbedded dolomitic marls and the isotopic studies (see

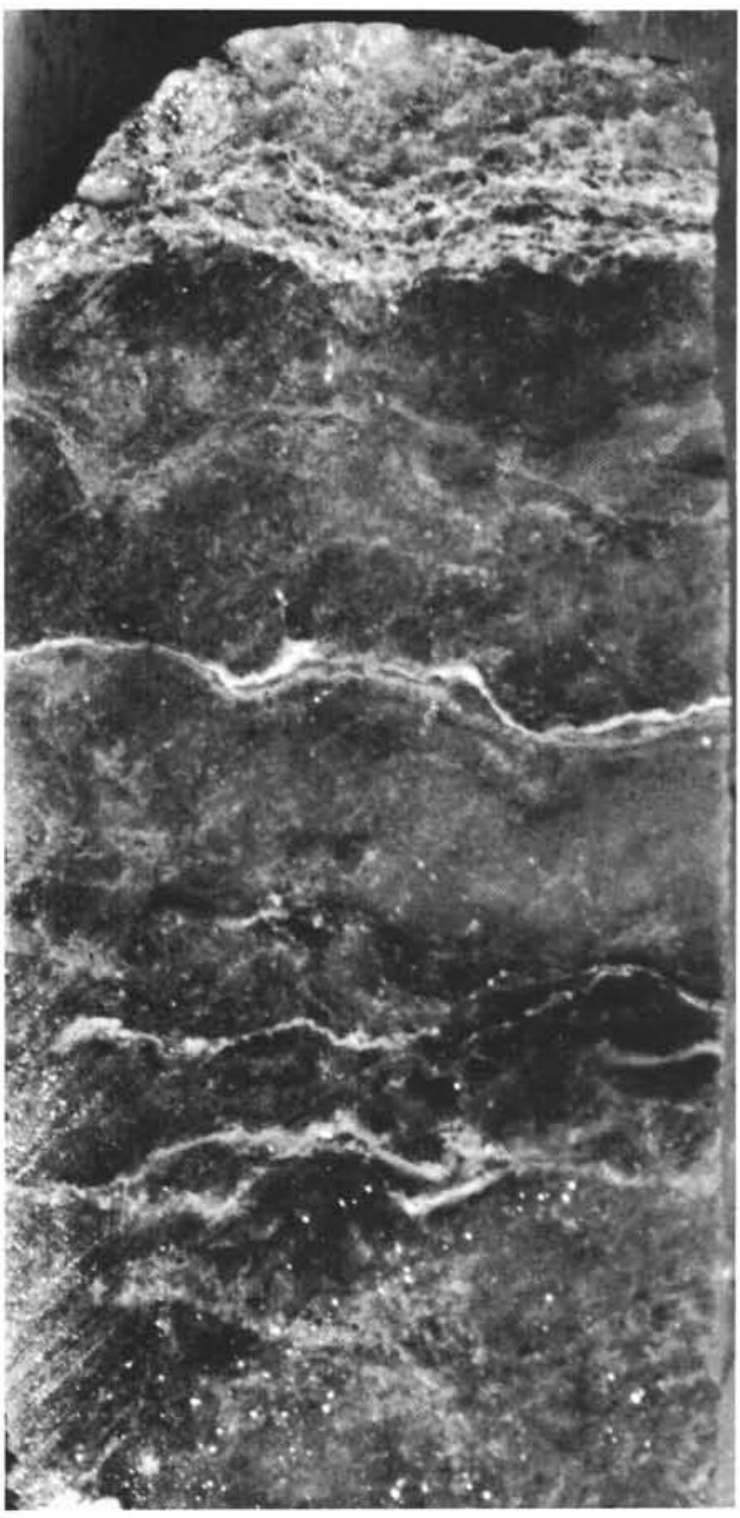

Figure 19. Pliocene/Miocene contact at Site 132 in the Tyrrhenian Sea. Light-colored brecciated pelagic nanno oozes, Pliocene in age, overlie darker laminated sandy marl ooze containing a dwarfed Messinian fauna. The contact is erosive but the faunistic succession is normal without an hiatus (132-21-2, contact at $76 \mathrm{~cm}$, on scale).

Chapter 30.2), agree with the petrographic findings in suggesting a shallow-water environment for deposition of the evaporites.

\section{SAPROPELS}

Dark brown to black sediments, known as sapropels (Ryan et al., 1971), were observed in all the Pliocene and Quaternary sections drilled in the eastern Mediterranean basin, with two exceptions. The first exception is the Strabo Mountains (Site 129) where no attempt was made to continuously core the post-Miocene section. The second is 
the Nile Cone (Site 131) with its thick accumulations of turbidites and grain flow deposits.

The sapropels are generally deposited under reduced (euxinic) conditions. The ones we recovered are characterized by a high organic content together with fair amounts of pyrite. They are poorly crystallized, the bulk of the sediment being formed by amorphous matter in amounts of up to 80 to 85 per cent. The remainder is made up of quartz, clay minerals, and carbonates. The fauna is poor, and Benthonic organisms are rare or absent.

The best examples of sapropels occur in the Ionian Sea, at Site 125, where the Pliocene Quaternary sedimentary column was continuously cored. They are thin, dark layers, 1 to $5 \mathrm{~cm}$ thick, sharply interbedded with light-colored pelagic oozes (Site 125, Cores 1, 3, and 2A).

At the other sites, the sapropels occur as part of turbidite or contourite sequences. In these cases, they are generally mixed with the coarser components such as sands and silts (Site 127, Cores 5 and 6; Site 128, Cores 3 and 4; etc.). Due to mixing, the color is of a lighter dark olive gray color. In the lower Quaternary, they are often associated with diatoms, the sediments appearing yellowish (Site 127, Cores 13 and 14; Site 128, Cores 8 and 10). This association of sapropels deposited under stagnant conditions, and turbidites, transported by strong currents, is remarkable. It suggests that the sapropels, deposited originally under euxinic conditions, were later eroded by turbidity currents and redeposited together with other sediments as part of a turbidite sequence.

In the Hellenic Trough, two horizons of sapropels were identified. The first, informally referred to as the "upper sapropel," occurs in the Geophyrocapsa oceanica Zone and a second, informally referred to as the "lower sapropel," occurs in the Pseudoemiliania lacunosa Zone. The Quaternary sapropels of the other sites also belong to these zones, suggesting a synchronous establishment of a euxinic regime in the entire eastern basin (see Chapter 23, Figure 1). In addition, upper Pliocene sapropels were noted at Site 125 (Core 2A).

The sapropel occurring in the first few meters below the sea floor surface in the eastern Mediterranean, and known from piston coring (Ryan et al. 1971), was not recovered during drilling.

\section{CONTINENTAL DEPOSITS}

At Site 133, located on the Sardinian margin near the Balearic Abyssal Plain, continental alluvium was penetrated between 60 and 192 meters, under a blanket of pelagic oozes.

The deposits are made up of pebbles, arenites and clays. They are barren of fauna and display variegated green and red colors. The gravels are well rounded and suggest a fluvial origin. These sediments are interpreted as continental deposits. They may be compared to the late Miocene fanglomerate deposits of the "Arenazzolo" (see Chapter 44.1 and Ogniben, 1957).

The discovery of continental alluvium on the edge of the subsided continental margin of Sardinia is important because it suggests a recent age for the subsidence. The association of evaporites at Site 134 with a proximal continental facies is an indication of shallow-water deposition of the evaporites.

\section{BASEMENT}

Basement rock was reached and recovered in the Atlantic (Site 120), in the Alboran Sea (Site 121), and on the Sardinian margin (Site 134). In addition, acoustic basement, which proved to be a thick ash deposit, was sampled in the Valencia Ridge (Site 123), and a mélange type rock was sampled in the Hellenic Trough (Site 121).

\section{Gorringe Bank}

At Site 120, basement was reached under 251.7 meters of sediment. Almost all the recovered material is a coarse-grained metagabbro. Large crystals, up to $3 \mathrm{~cm}$, include gray feldspar and tan bronzite, together with smaller crystals of olivine, fibrous chrysotile, and some serpentinized pyroxene. Chips of a fine-grained rock resembling a spilite of the Alpine ophiolite suite and chips of serpentinite were also recovered, together with fragments of radiolarian chert ("Steinmann trinity" of Alpine-Apennine geologists). See Chapter 26, for detailed petrography.

\section{Alboran Sea}

Basement was reached at Site 121 under 864 meters of sediment. A breccia overlay a large fragment of gneiss, jammed in the core bit. The breccia contains rock fragments of variable petrography: kinzigite, cordierite, leptynite, marble, gneiss, and granite. This assemblage suggests a metamorphic suite. See Chapter 27 for detailed petrography and discussion.

\section{Sardinian Margin}

The buried Sardinian margin was reached in five holes (134A to E). All yielded pieces of dark olive gray semi-schists with sharp schistosity planes. They are composed of quartz, plagioclase, seriticized plagioclase, hornblende, epidote, etc., in a micaceous matrix. The recovered semi-schists are similar to the Cambrian, Devonian, and/or Carboniferous semi-schists and phyllites of Sardinia. For detailed petrography and discussion see Chapter 29.

\section{SPECIAL PROBLEMS}

\section{Unconformities and Hiatuses}

Unconformities and hiatuses were noted at almost all sites, reflecting the complex geology of the Mediterranean Basin and the Atlantic Ocean.

In the Atlantic at Site 120, located on the Gorringe Bank, a major hiatus ( $80 \mathrm{my}$ ) was suspected between the Miocene and the lower Cretaceous, but was not cored. Similar hiatuses were observed in other Atlantic sites such as $105,118,119,135,136,138$, etc. (Hollister, C. D., Ewing, J. L. et al., 1972; Laughton, A. S., Berggren, W. H. et al., in press; Hayes, D. E., Pimm, A. C. et al., in press). Thus it seems that a general phenomenon at that time produced a period of nondeposition or even erosion. As these hiatuses were also observed in some Pacific sites (Fisher, A. G., Heezen, B. C., et al., 1971) this phenomenon may have affected the world ocean.

In the Mediterranean Sea, the most common hiatuses occured between the Messinian evaporites and the overlying Pliocene-Quaternary deposits. They correspond to the 
flooding of the dessicated Messinian basin by the Pliocene sea. In some sites, this flooding seems to have resulted in an important erosion, as in the Alboran Sea (Site 121), while at other sites the time gap is small (see Site Chapters 121, $122,124,125,132$, and 134).

More discrete hiatuses were noted in some Pliocene and Quaternary sedimentary columns. At Site 122, the middle Quaternary turbidites overlie upper Pliocene turbidites, suggesting erosion. In Hole 134E a boundary, interpreted as a hardground, separates Pliocene and middle to late Quaternary pelagics.

In the last group, the hiatuses fit in with the local geological settings. In the Valencia Gulf, Site 123, Pliocene turbidites overlie a body of volcanic ash of Miocene age. On the Mediterranean Ridge, at Site 126, Quaternary turbidites fill a valley eroded down through the sequence to Serravalian marls. On the subsided Sardinian margin, pelagic oozes directly overlie the basement (Holes 134A, B, C, and E) and continental deposits (Site 133). Finally, remarkable unconformities are noted in the tectonically disturbed mélanges of the Hellenic Arc (Sites 127 and 129).

\section{Rates of Accumulation}

The sedimentary rates estimated in the Leg 13 drillings are consistent with the previously published data. In the Atlantic, the only interval for which a calculation was reasonably attempted is the lower Cretaceous. Here, the pelagic marl oozes were accumulated at a rate of 0.4 $\mathrm{cm} / 10^{3} \mathrm{y}$. This rate is low but comparable to those of other foraminifera-free nanno oozes in the Atlantic (Maxwell, A. E., von Herzen, R. P. et al., 1970).

In the Mediterranean Sea, the pelagic oozes of Pliocene and Quaternary age accumulated at rates varying generally from $1.6 \mathrm{~cm} / 10^{3} \mathrm{y}$ (Site 125 , Quaternary) to $3.5 \mathrm{~cm} / 10^{3} \mathrm{y}$ (Site 132, Quaternary). An exception is the Quaternary hemipelagic marl ooze of the Alboran Sea (Site 121) with a rate of $19.9 \mathrm{~cm} / 10^{3} \mathrm{y}$. It probably corresponds to a local high productivity regime.

Our only computed example of Mediterranean compacted pelagics is from the Tortonian of the same Alboran site, 121 , with $2.8 \mathrm{~cm} / 10^{3} \mathrm{y}$.

The rates of accumulation of turbidites and contourites are highly variable. Some are exceptionally low, such as 4.3 $\mathrm{cm} / 10^{3} \mathrm{y}$ for the Valencia Gulf (Site 123) Pliocene turbidites, which probably reflects erosion. The general value is 6 to $9 \mathrm{~cm} / 10^{3} \mathrm{y}$ when turbidites are associated with contourites on continental margins (Site 124) or in peripheral basins such as the Alboran Sea (Site 121) and Valencia Gulf (Sites 122 and 123). In the Hellenic Trench, the figure is higher, $26 \mathrm{~cm} / 10^{3} \mathrm{y}$ (Sites 127 and 138). The highest values correspond to the submerged Nile Cone, at least $55 \mathrm{~cm} / 10^{3} \mathrm{y}$. With regard to the discharges of major rivers, this last value is comparable to the $38 \mathrm{~cm} / 10^{3} \mathrm{y}$ noted in the Gulf of Mexico (Ewing, Worzel, et al., 1969), and to the $70 \mathrm{~cm} / 10^{3} \mathrm{y}$ observed in the Vema Fracture Zone.

In order to verify that the top of the recovered stratigraphic column represented the real sea floor surface, or alternatively if some sediments were bypassed, the accumulation rates were checked by radiocarbon dating of subsurface samples in the two pelagic sites, 125 and $132 .^{3}$

At Site 125 on the Mediterranean Ridge in the Ionian Basin, we suspected that part of the youngest section was missing (see Chapter 7). This suspicion was aroused when we did not find a sequence of sapropels and ash layers in Core 1 similar to those recovered in nearby piston cores (Olausson, 1965; Strick and Pastouret, 1971). In later stratigraphic investigations of the Site 125 cores, the recovered sample of Cores 1 and 2 have been correlated to a level of about 400 to 500 thousand years (see Chapter 46, Figure 12). Independent radiocarbon dating carried out on a sample $80 \mathrm{~cm}$ below the top of the recovered sedimentary column, yielded an age of $31,000 \pm 1700$ years, which would suggest that no bypass occurred. We are unable at present to explain this discrepancy.

Similarly, on the Mediterranean Ridge, opposite the Nile River (Site 130), a sample from the surficial blanket of pelagic nanno ooze, $110 \mathrm{~cm}$ below the supposed sea floor surface, showed no radiocarbon activity. If we tentatively estimate the age of this sample at 35,000 years, the top 110 $\mathrm{cm}$ would have been deposited at a rate of $3 \mathrm{~cm} / 10^{3} \mathrm{y}$. This figure is slightly higher than the supposed average for the Quaternary in this region. However it is consistent with the figure obtained for Site 125, and suggests that the top of the sedimentary column is the real sea floor.

\section{Induration}

Lithification and cementation processes were noted in almost all the Leg 13 sites.

In the Atlantic Ocean, the pelagic series of Gorringe Bank (Site 120) is unconsolidated at the top of the sedimentary column. The marls become semi-indurated at 226 meters in Core 6, of Aptian age, and indurated and brittle at 229 meters in Core 7, of Barremian age.

In the Mediterranean Sea, the Miocene preevaporitic sediments are generally indurated. This is the case of the Tortonian marls of the Alboran Sea (Site 121), the Serravalian marls of the Mediterranean Ridge (Site 126), and the Langhian marls and limestone of the Strabo Mountains (Site 129). As an exception to this, the Serravalian dolomitic marls and lower Messinian brackishwater oozes of this last site (129) are not indurated.

The Messinian evaporitic series is fairly indurated and displays massive beds of rock salt, halite, and gypsum (see Chapter 21). However, the last 50 or so meters of the top of the formation, comprising marls and dolomitic marls, are often still plastic.

The younger deposits, Pliocene and Quaternary in age, are generally plastic, but induration and cementation do occasionally occur with depth. In the turbidite series of the Alboran Sea (Site 121), the first sandstone occurs at 349 meters downhole. The marl oozes remain plastic and are noticeably indurated at 737 meters.

On the Balearic margin, marl ooze layers of the Site 124 turbidites are semi-indurated at 336 meters.

At Site 131, the turbidites of the submerged Nile Cone contain the first indurated marls at the shallow depth of 93

\footnotetext{
${ }^{3} \mathrm{C}^{14}$ dating was done by Fontes (method described in Fontes (1971))
} 
meters, while the first sandstone is noted more than fifty meters below, at 141 meters. In the more distal Site 130, the marl oozes are only semi-indurated at 258 meters. However, thin centimetric layers of limestone occur at the same level and the first sandstone is found at 554 meters.

In the Strabo Mountains area, the data is less conclusive. Pieces of limestone and sandstone of unknown age were recovered near the surface at Site 129, and a thick body of faunally barren and partly consolidated sand was recovered in Hole 129B. Due to the steep slope at this site and the strong possibility of the presence of a tectonic mélange, the consolidated rocks may be either slumped blocks or in situ consolidated sediments.

In conclusion, in the Mediterranean Sea the consolidation of marine sediments seems to be related more to depth of burial than to age. Generally, the minimum depth of consolidation is 300 meters for sands and marl oozes, but exceptions are frequent.

\section{REFERENCES}

Baldacci, L., 1886. Descrizione geologica dell'Isola di Sicilia. Mem. Descrittive Carta Geol. Italia. 1, 403.

Bouma, A. M., 1962. Sedimentology of some flysch deposits. Elsevier. Amsterdam, New York.

Civetta L., Gasparini P. and Adams J. A. S., 1970. Geochronology and geochemical trends of volcanic rocks from Campania, S. Italy Ecolgae Geol. Helv. 63(1), 57.

Dzulynski S., Ksiakiewicz M. and Kuenen Ph. H., 1959. Turbites in flysch of the Polish Carpathian Mountains. Bull. Geol. Soc. Am. 70, 1089.

Ewing, J. L., Worzel, J. L. et al., 1969. The Initial Reports of the Deep Sea Drilling Project, Volume I. Washington (U.S. Government Printing Office).

Fisher, A. G., Heezen, B. C. et al., 1971. The Initial Reports of the Deep Sea Drilling Project, Volume VI. Washington (U. S. Government Printing Office).

Fontes, J. Ch., 1971. Un ensemble destiné à la mesure de l'activité du radiocarbone naturel par scintillation liquide. Rev. Geogr. Phys. Géol. Dyn. (2) 13, (fasc. 1), 67 .

Hayes, D. E., Pimm, A. C. et al. The Initial Reports of the Deep Sea Drilling Project, Volume XIV. Washington (U.S. Government Printing Office). In press.

Hollister, C. D., Ewing J. L. et al., 1972. The Initial Reports of the Deep Sea Drilling Project, Volume XI. Washington (U. S. Government Printing Office).

Hollister, C. D., 1967. Sediment distribution and deep circulation in the western North Atlantic. Ph. D. Thesis-Lamont Geological Observatory. Columbia University., N. Y.

Huang T. C. and Stanley D. J., 1972. Sediment dispersal and ponding in the Alboran sea during late Quaternary time. In, "Sedimentation in the Mediterranean Sea", D. J. Stanley ed., Hafner Publishing Co., N. Y.

Laughton, A. S., Berggren, W. H. et al., The Initial Reports of the Deep Sea Drilling Project, Volume XII. Washington (U.S. Government Printing Office). In press.

Maxwell, A. E., von Herzen, R. P. et al., 1970. The Initial Reports of the Deep Sea Drilling Project, Volume III. Washington (U. S. Government Printing Office).

Nesteroff, W. D., 1962. Essai d'interprétation du mécanisme des courants de turbidité. Bull. Soc. Géol. France (7). 4,849

Ogniben L., 1957. Petrografia della serie solfifera siciliana e considerazioni geologiche relative. Mem. des. carta Geol. Italia. 33, 1.

Olausson, E., 1965. Evidence of climatic changes in North Atlantic Deep-Sea Cores. Progress in Oceanography. Pergamon Press, London. 3, 221.

Rossignol, M. and Pastouret, L., 1971. Analyse pollenique de m'veaux sapropelitiques, post glaciaires dans une carotte en Mediterranee Orientale. Rev. Palaeobot. Palynol. In press.

Ryan, W. B. F., Stanley D. J., Hersey J. B., Fahlquist D. A. and Allan T. D., 1971. The tectonics and geology of the Mediterranean sea; In The Sea. John Wiley and Sons, N. Y., 4, 387.

Wezel, F. C., 1970. Geologia del Flysch Numidico della Sicilia nord-orientale. Mem. Soc. Geol. Italia. 9, 225. 